known, and, without doubt, consists of two atoms of phosphorus, united with five atoms of oxygen, whereas Berzelius only found three atoms of exygen to two of the rare metal in vanadic acid. How is this discrepancy to be explained? We have here to do either with an exception to the otherwise general law of isomorphism, so that we may have identity of crystalline form, without any analogy in chemical composition, or Berzelius's experiments and conclusions respecting the constitution of this vanadic acid are incorrect. By experiments on the properties of vanadium and its compounds, made with much larger quantities than it fell to the lot of the Swedish chemist to work with, it was shown that something had been overlnoked by him. It was proved that the substance which he supposed to be a metal was not a metal at all, but an oxide, and that vanadic acid really contains more oxygen than he believed it to contain. And what is remarkable is that this quantity of oxygen, which had been overlooked, is exactly the quantity which is needed in order to make the constitution of vanadic acid identical with that of phosphoric acid. We have to take out of each atom of Berzelius's metal one atom of oxygen in order to get the true vanadium, so that the real atomic weight of this element is less than that giren to it by Berzelius by the atomic weight of oxygen, $67^{\circ} 3-16=5 \mathrm{r} \cdot 3$. Thus the chemical constitutions of phosphoric and of vanadic acids are represented by the formule $\mathrm{P}_{2} \mathrm{O}_{5}, \mathrm{~V}_{2} \mathrm{O}_{5}$. The law of isomorphism remains unassailed, and the goddess (Vanadis is a cognomen of the Scandinavian goddess Freia) who was found wandering as a waif and a stray amongst her companion elements, has been restored to her natural friends, and now forms a recognised member of a family group.

To sum up, my aim in the foregoing remarks has been to show that if freedom of inquiry, independence of thought, disinterested and steatfast labour, habits of exact and truthful observation, and of clear perception, are things to be desired as tending to the higher intellectual development of mankind, then original research ought to be encouraged as one of the most valuable means of education. And that on this ground alone, and independent of the enormous material benefits which such studies confer on the nation, it is the bounden duty not only of the Guvernment, but of every educational establislnnent, and of every citizen of this country who has the progress of humanity at heart, to promote and stimulate the growth of original research amongst us.

\section{HELVETIC SOCIETY OF NATURAL SCIENCES}

TIIE fifty-sixth annual meeting of this society was held on the ISth, Igth, and 2oth of August last, at Schaffhouse, under the presidency of Dr. Stierlin, and is described as having been a highly animated one. We shall note a few of the more im. portant papers presented; for particulars of which we are indebted to the Archives des Sciences.

In the section of Physics and Chemistry, M. Soret described a method for studying ultra-violet spectra. It consists in placing a thin fluorescent lamina (sulphate of quinine, e.g. between two glass plates) before the eyepiece of a spectroscope, where the image is formed, and observing, with sufficient inclination of the eyepiece the image of the ultra-violet spectrum then developed on the lamina. Prof. Kopp read a paper on bresiline and its derivatives. The Deacon process of manufacturing chlorine was the subject of a papar by M. IIurter, which gave rise to lively dis. cussion. Dr. Heim, who has been observing the sounds of cascades, find they all give the note $C$ sharp, or $F$.

In Geology, Dr. Schalch had a paper on the volcanic rocks of Höh yau. These are in two groups, that of basalts, and that of phonolites. They form isolated cones surrounded with thick deposits of volcanic tufa, the nature and arrangement of which indicate that the eruptions ha ppened at successive intervals about the end of the tertiary epoch. M. Favre showed a section of the Vaudois Alps made at Pleiades, near Vevey aux Ormonts; in which he distinguishes three zones, consisting of superior Jurassic and Necomian, and different portions of Eocene, strata. Mr.Heim exhibited a new method of geological representation of a country; it consists in a series of sections, on the same scale, coloured and fixed vertically at equal distances on a geological map. Ife also made some observations on the zone of contact of crystalline rocks and sedimentary strata in Eastern Switzerland and the Bernese Alps. M. Lang announced the early publication, by the Alpine Club of a glacier-register, in which information will be given as to dimensions, form progress, \&c., of glaciers. At the first general séance Prof. Heim gave a valuable resume of the various theories of glacial motion. At the second, Prof. Desor presented a memoir on morainic landscapes, by which he denotes those indicating a former extension of glaciers. The most striking types are at the southern base of the Alps. There is discernible a zone consisting of a succcssion of verdant hillocks, sometimes aligned, sometimes separate; these are found to be composed of the débris of old formations bruised and triturated, and clearly indicating glacial action. A good example occurs at the base of Monte Campo di Fiori.

At the general opening siance Prof. Forel gave an account of his researches on the deep-water fauna in Lake I eman, of which he enumerates some thirty species. If had also studied the fauna of the lakes of Neuchatel, Zurich, and Constance. His conclusions are briefly these:- There are in the lal es three distinct fauna: $(a)$ a littoral, extending to 15 or 20 metres depth ; (b) a deep, fauna, from 20 to 300 metres; and (c) a pelagic fauna. All the forms of the deep fauna have analogous or similar forms in the littoral fauna ; but the converse does not hold, At the same level the deep fauna are the same. A few species found between 30 and 100 metres are not found at 300 metres. but all the types at 300 metres are found between 30 and 100 metres. There are local and seasonal differences. The deep fauna are best studied between 30 ani 60 metres. In comparing different lakes the general characters of deep fauna are the same, but special characters vary.

In the section of zoolngy and botany, MI. Bugnion described some sensitive organs found in the epidermis of Proteus and Axolotl. They are considerably developed in the former (1460 were counted in one specimen), and are disposed in linear groups of three or four along certain nerves of the head, and the lateral nerve to the end of the tail. They resemble the cyathiform rrgans discovered by $\mathrm{MI}$. Leydig in $\mathrm{I} S 5_{\mathrm{O}}$, in the epidermis of fishes. Dr. Cartier gave a paper on the sensitive hairs of crocodiles.

In the medical department Prof. Karsten, of Vienna, made a communication on necrobiosis in which he pointed out that Bacteria, Vibriones, and micro-coceus, \&s., are not to be re sarded as organic species, properly so called; the phenomena of animal reproinctlon lave never becn observed in them. They are pathor logical products, which grow in the interior of vegetable or animal cells, but which do not penetrate these when once developed, as parasites.

In the department of Pure Mathematics the principal paper was by Prof. Schwarz on a new example of a continual function which does not admit of derivatives. This paper will be found in crtenso in the Archives.

This is the third time in its history that the Helvetic Society has met at Schafflouse, the former occasions having been in IS25 and I 847 . The next annual session is to be held at Coire.

\section{SCIENTIFIC SERIALS}

Sitzungsberichte der Königl. Böhmischen Gesellschaft der Wissenschaften in Prags. Jan. IS71 to June I872. (3 numbers). -Among the more valuable matter in these numbers may be noted some contributions to palxontological botany; more especially a paper by MI. Feistmantel describing the various fruit-forms met with in Bohemian coal formations. (As published separately, the paper contains several excellent plates). The same author communicates also full accounts of the flora in coal-measures at the foot of the Riesengebirge, and at Merklin. -M. Dvorak describes some curious experiments on individual differences between the two eyes, and between different parts of the retina of the same eye. He shows that two non-simultaneous impressions, each affecting one eye, appear simultaneous, when the time.interval is of a certain length; this interval he measures with suitable apparatus. - In chemistry we have a note by Prof. Stolba, giving a new method of preparing borofluoride of potassium, and an account of the properties of this substance.Dr. Weyr investigates mathematically the distance-action of electrical sclenoids on material plane surlaces; and a note by M. Domalip furnishes experimental proof of certain laws deduced by M. Dub as to the dependence of magnetic moment on the dimensions of a magnetic bar. - There are also papers on the fauna of lakes in the Böhmerwald, on basaltic formaticns, and on several points in mineralogy and pure mathematics.

Bullctin ae l'Acadimie Royalc de Bilsiqui, No. S, I873.-In this number is described a recording metiorograph, devised by II. Van Rysselberghe, and which seems to have some merit; 